\title{
Economic Reconstruction Amidst Conflict: Insights from Afghanistan and Iraq
}

\author{
Christopher J. Coyne* \\ Department of Economics \\ George Mason University \\ MSN3G4, Fairfax, VA 22030 \\ ccyone3@gmu.edu \\ Adam Pellillo \\ Department of Economics \\ West Virginia University \\ PO Box 6025, Morgantown, WV 26506 \\ adam.pellillo@mail.wvu.edu
}

\begin{abstract}
Economic reconstruction typically takes place after the end of war. Yet recently, economic reconstruction has been viewed as a means to 'win hearts and minds' during ongoing conflict. Drawing on a variety of reconstruction experiences from Afghanistan and Iraq, we identify four 'reconstruction traps' that result from the incentives and constraints faced by actors involved in economic reconstruction during ongoing conflict. These traps include: (1) the credible commitment trap, (2) the knowledge trap, (3) the political economy trap, and (4) the bureaucracy trap. Avoiding these traps is critical for successful economic reconstruction and we discuss strategies for doing so.
\end{abstract}

JEL Codes: D03, D73, D74

Keywords: economic reconstruction, credible commitment, knowledge, political economy, bureaucracy, post-conflict reconstruction 


\section{INTRODUCTION}

Economic reconstruction involves fundamentally transforming a society's economic institutions in order to foster growth and development as well as to resolve perceived economic and social problems. In many conflict and post-conflict settings, infrastructure has been destroyed and roads, power stations, water pipelines, hospitals, schools, and sewerage facilities must be completely rebuilt. In addition to the destruction of physical capital, human capital and social capital are seriously damaged by conflict. The economic reconstruction process as a whole therefore involves rebuilding infrastructure, restoring physical, social, and human capital, and restructuring fiscal, monetary, and trade policies in order to allow for a robust private sector to emerge.

Historically, economic reconstruction has taken place following the end of conflict, as in the cases of post-World War II Japan and West Germany. However, in more recent foreign interventions such as Afghanistan and Iraq, economic reconstruction has been viewed as part of a broader strategy to "win the hearts and minds" of domestic political authorities, citizens, and insurgents in order to end conflict. Economic reconstruction in such contexts has proven to be highly complex and uncertain.

For example, many economic reconstruction projects have been relatively successful in both Afghanistan and Iraq - the rebuilding of schools, hospitals, and infrastructure has taken place despite the presence of violent insurgencies. School enrollment has skyrocketed in Afghanistan and girls, who were previously unable to attend school under Taliban rule, now comprise a third of the country's education enrollment (Isby 2010; Miliband 2010). Nonetheless, there have also been significant setbacks due to ongoing conflict in addition to a 
variety of other factors discussed in this paper. Insurgents often target aid workers as well as infrastructure projects that have been administered by foreign reconstruction authorities.

In Iraq, for instance, insurgents often targeted oil pipelines and other major infrastructure programs administered by the U.S. and its allies. Gul Agha Ahmadi, a spokesman for the Ministry of Education in Afghanistan, has reported that around 60 schools have been burned down in 2010 at the time of writing (Norland 2010).

Despite the importance of economic reconstruction, the topic has received relatively little attention from the academic community. As Del Castillo (2008: 19-20) notes, “...economic reconstruction has been a much-neglected aspect of the extensive and fast-growing literature on war-to-peace transitions." This is especially the case in the context of ongoing insurgencies in Afghanistan and Iraq. The purpose of this paper is to fill this gap in the literature by analyzing economic reconstruction amidst ongoing conflict in Afghanistan and Iraq.

Our analysis is situated in multiple strands of related literature. Since post-conflict reconstruction typically involves social and economic change in the broadest sense, some of the literature on the topic assesses the multiple facets of rebuilding a society's economic, legal, political, and social institutions in the wake of conflict (see Kumar 1998; Ikenberry 2001; Bastian, Sunil, and Robin Luckham 2003; Chimni 2003; Demekas, McHugh, and Kosma 2003; Williams 2003; Coyne 2008; Coyne and Boettke 2009). Others provide historical contexts for reconstruction activities or critically assess international donors' plans for development in postconflict societies (Montgomery and Rondinelli 2004). Another strand of literature on reconstruction has focused more specifically on the economic aspects of reconstruction, such as fiscal and monetary policies or infrastructural development. For example, the contributors to the volume edited by Boyce (1996) explore the economic policies conducive to peace based on 
reconstruction experiences in El Salvador. Boyce (2002) highlights the role of conditional aid in encouraging domestic investment in peace. Adam et al. (2008) analyze the role played by aid in monetary reconstruction. Del Castillo (2008) emphasizes that post-conflict economic reconstruction is a multi-pronged challenge which involves standard issues of socio-economic development as well as the need to consolidate peace and provide basic services to citizens. Collier (2009) analyzes whether post-conflict economic policies should be distinctive from those adopted in equally poor, but peaceful, countries.

Our analysis differs from, and contributes to, this existing literature in several important ways. First, in contrast to the first category of literature on post-conflict reconstruction, we focus on one specific aspect of reconstruction-reforming economic institutions. Second, the existing literature tends to neglect the different incentives and constraints facing the array of actors involved in economic reconstruction — domestic and foreign policymakers, aid workers and development experts, members of the military, diplomats, etc. Currently, much of the literature is focused on identifying the challenges involved in economic reconstruction, as well as the ideal policies necessary to address these challenges. While identifying challenges and solutions is clearly important, it is only part of the story. Also important is the ability to actually design and implement policies in a way that effectively address the challenges of economic reconstruction. Third, our analysis focuses on economic reconstruction in the context of ongoing insurgencies. Much of the existing literature is focused on economic reconstruction efforts that take place in post-conflict settings and therefore assumes that economic reconstruction takes place in an environment where conflict is minimal or has altogether ended. However, as the insurgencies in Afghanistan and Iraq illustrate, this has not recently been the case. Given our focus on economic reconstruction amidst ongoing conflict and insurgency, our analysis places particular emphasis 
on the role played by military officials, in addition to other key players involved in economic reconstruction. Neglecting how ongoing conflict and insurgency influences economic reconstruction efforts overlooks potential sources of tension between various, and often competing, goals-e.g., military, diplomatic, peace building, economic reconstruction and development, etc. This is crucial given that economic reconstruction rarely takes place in isolation and is typically part of a broader policy agenda which includes state building and peace building.

To date, these aspects of economic reconstruction have not received the attention they deserve. Our central argument is that the array of actors involved in economic reconstruction efforts face different incentives and constraints which influence their ability to effectively design and implement economic reforms and reconstruction projects. These constraints exist in all economic reconstruction efforts, but become increasingly complex and relevant in cases where conflict is still ongoing such as Afghanistan and Iraq.

We identify four main 'reconstruction traps' which often hamper efforts to rebuild economies amidst conflict. These traps include: (1) the credible commitment trap, (2) the knowledge trap, (3) the political economy trap, and (4) the bureaucracy trap. In order to illustrate the dynamics of each trap, we draw from a variety of experiences in Afghanistan and Iraq. Avoiding these traps is critical for success in economic reconstruction so we discuss potential strategies for avoiding them in current and future reconstruction efforts.

In what follows, we dedicate a section to each of these four economic reconstruction traps. We discuss the dynamics of each trap and also consider strategies to avoid the pitfalls created by these traps. The final section concludes with the implications of our analysis. 


\section{THE CREDIBLE COMMITMENT TRAP}

The credible commitment problem can be understood as follows. Without a binding and credible commitment to economic reforms (e.g. reconstruction projects or fundamental changes to fiscal, monetary trade, or regulatory policies), some reconstruction officials may have the incentive to change course in the future. ${ }^{\mathrm{i}}$ If this is the case, then economic reforms will be time inconsistent. Time inconsistency of reforms results in regime uncertainty - the instability of rules and institutions over time-which threatens the likelihood of success in broader efforts to end conflict and reconstruct the economies of war-torn societies.

The credible commitment problem has been identified as one of the most significant impediments to effective post-conflict economic reconstruction (Coyne and Boettke, 2009; Flores and Nooruddin, 2009). As we discuss below, the credible commitment trap may emerge because the operational environment is inherently dynamic. The inability to make a credible commitment may also be a function of the complexity caused by the interactions of multiple reformers (e.g. U.S. military officials, Afghan national government officials, aid organization officials, local warlords, etc.), some of which may perceive that they must change their strategies given new developments or have competing objectives.

\section{The credible commitment problem}

To illustrate the dynamics of the credible commitment trap, consider that regime uncertainty has hindered economic reconstruction efforts in Iraq and Afghanistan. As oft-cited examples, in Iraq, the initial governing authority - the Coalition Provisional Authority (CPA) - reneged on an economic reform regarding the privatization of state owned enterprises (SOEs) after seeing how the initial privatization subsequently affected unemployment and the economy in general. While 
essentially unintended, this reform reversal likely led many Iraqi citizens and local political authorities to question the legitimacy of future economic reforms announced by the CPA.

In the case of Afghanistan, constant changes to the general policy environment by the military occupiers have contributed to fundamental and widespread uncertainty on the part of Afghan leaders and citizens. As Stewart (2010) explains,

We [the U.S. and its allies] armed militias in 2001, disarmed them through a demobilization program in 2003, and rearmed them again in 2006 as community defense forces. We allowed local autonomy in 2001, pushed for a strong central government in 2003, and returned to decentralization in 2006. First we tolerated opium crops; then we proposed to eradicate them through aerial spraying; now we expect to live with opium production for decades.

This lack of commitment to a particular policy framework, while necessary for a dynamic and flexible approach to economic reconstruction amidst conflict, can inadvertently hinder the credibility of future policies of foreign governments and international organizations. ${ }^{\text {ii }}$ Such drastic changes in policy imply that both the Afghan national government and foreign reformers will be seen as lacking commitment to a continuous policy regime. In the context of an ongoing insurgency, credible commitments to reforms become incredibly difficult because there are multiple reconstruction officials and domestic political authorities vested with decision making power. External policymakers (e.g. officials from UN Agencies, USAID, U.S. State Department, the World Bank, International Monetary Fund, Asian Development Bank, various NGOs, etc.) and military occupiers (e.g. U.S. coalition forces, NATO forces, the CIA, etc.) can be construed as one set of reformers while domestic political leaders, warlords, and insurgents at the national and local levels are another. The dispersion of policy decision making power among different reconstruction officials and political authorities makes avoiding the credible commitment trap that much more difficult because determining and establishing the appropriate incentives for reformers at each level is an extremely difficult task. Regime uncertainty on the part of one 
group of policy makers can make credible commitments to reforms by other groups of policy makers tenuous.

Along with fragmentation in policy decision making power, social fragmentation also complicates the ability of different reconstruction officials to make credible commitments to a specific policy regime. Consider that in Iraq, successful economic reforms needed to satisfy members of Iraq's major ethnic groups — the Arabs and the Kurds—and religious groups—-Shi'a and Sunni Muslims. In reality, the situation is even more complex given that there are various intra-group factions in the broader Sunni and Shi'a groups in Iraq at both the national and local levels (Fearon 2007). This is also the case with Afghanistan's ethnic groups with ethnic Pashtuns, Tajiks, Hazaras, Uzbeks, and many other groups all comprising power in Afghan governance (national and local). Finding a policy consensus to which the various reformers can commit under ethnic fractionalization or polarization is especially daunting in these situations, as the commitment to a specific policy may isolate a particular ethnic group or renege on a promise to these individuals.

An existing literature on reform, peace building, and aid effectiveness highlights the importance of domestic policy ownership (see Sobhan 2002). As put by World Bank President Robert Zoellick (2008), "local ownership is key to achieving legitimacy and effectiveness." The underlying idea is that without domestic buy-in and ownership, economic reforms will not stick and operate in the desired manner. Local policy ownership also obviates the need to coordinate the efforts of multiple reconstruction officials, some who have competing objectives and visions for economic reconstruction.

Yet with policy decision making power dispersed among numerous domestic policy makers, policy ownership is still highly complex. With competing objectives even among 
different domestic political authorities, allowing for policy ownership implies that some economic reforms will be adopted that will be discordant with others. The problem is further exacerbated by ongoing conflict because reconstruction officials and citizens cannot be sure about what the distribution of power will be when conflict does end. This further contributes to the uncertainty regarding who the true 'reformers' are which weakens the credibility of announced reforms at various levels.

As this illustrates, the credible commitment problem poses a great deal of complexity and uncertainty for reconstruction officials. Historically, credible commitments in Afghanistan have been difficult. The problem facing foreign reconstruction officials is twofold. First, they must determine what exactly domestic legitimacy entails. Is legitimacy a function of the ability to make a credible commitment or is it moreover a problem of misaligned expectations among local citizens and political authorities? Second, foreign reformers have to allow for domestic ownership over economic reforms. This is hard enough in post-conflict settings, but ongoing conflict makes the challenge that much more difficult.

While the establishment of legitimacy is seen as the main objective of counterinsurgency (COIN) and reconstruction operations by the U.S. military (U.S. Army/Marine Corps, 2007: 121; U.S. Department of the Army, 2008: 1-7.), supporting the legitimacy of host nations and promoting domestic policy ownership can be a difficult task. In order for domestic ownership to be established, domestic political authorities and citizens alike must have the incentives to coalesce around specific economic reforms. Consider that the National Solidarity Program, a World Bank-administered development aid program in Afghanistan, requires that each community contribute ten percent toward the cost of each project (in either financial or labor contributions) (Isby 2010: 363). This allows for ordinary citizens to have a stake in each project. 
Citizen involvement also pressures local political authorities to become involved in the development and security of reconstruction projects. However, such local ownership assumes that that there is an incentive to not only initiate reconstruction projects, but also to maintain them over the long run.

\section{Strategies for avoiding the credible commitment trap}

Establishing the legitimacy of reconstruction officials and economic reforms is a crucial element of successful economic reconstruction. Yet finding solutions to the credible commitment trap is not simply a matter of establishing constraints on reformers. Those engaged in economic reconstruction efforts must simultaneously establish binding constraints on their courses of action and strongly signal to citizens and local political authorities that they are sincere in committing to their announced reforms. By doing so, repeated interactions between reconstruction officials and local citizens, as well as political authorities, can shift the equilibrium from a 'one shot' situation, where reformers may have the incentive to renege on their vocalized course of action or local citizens may not buy in to specific reforms, to an equilibrium of cooperation between citizens and those involved in leading reconstruction efforts.

Filkins (2009) describes a discussion between General Stanley McChrystal, the former commander of U.S. troops and the International Security Assistance Force (ISAF) in Afghanistan, and Abdullah Jan, a governor in Garmsir in Afghanistan, which captures the essence of the credible commitment problem in economic reconstruction. Abdullah Jan told Gen. McChrystal the following:

Everyone in Garmsir sees that you are living in tents, and they know that you are going to be leaving soon. You need to build something permanent---a building. Because your job here is going to take years. Only then will people be persuaded that you are going to stay. 
What Jan is expressing is the importance of reformers signaling a credible commitment to a future course of action. Absent such a signal, citizens will not see the future course of actions espoused by external reformers as legitimate.

Along with signaling credibility, reconstruction officials must seek to promote transparency and accountability, both within the Afghan and Iraqi national governments but also within their own operations. While such anti-corruption measures would be ideal if implemented in the first order, they clearly are not. This is likely to be due to the competing objectives of different reconstruction officials in the country. As a case in point, Mohammed Zia Salehi, an aide to the Karzai administration, was arrested on corruption charges but Karzai subsequently secured his release from prison. Later revelations indicated that Salehi was on the CIA's payroll. As described by Filkins and Mazzetti (2010), "Mr. Salehi's relationship with the CIA underscores deep contradictions at the heart of the Obama administration's policy in Afghanistan, with American officials simultaneously demanding that Mr. Karzai root out the corruption that pervades his government while sometimes subsidizing the very people suspected of perpetrating it."

One strategy for overcoming credible commitment problems is for reconstruction officials to go overboard with reforms to signal the strength of their commitment to a stable policy regime (see Rodrik 1989). As an example where this strategy could be relevant, consider the case of Iraq, where private entrepreneurship is stifled by excessive regulations and corruption which raise the cost of opening a business (see Gunter, 2009). In order to signal a credible commitment to reform and support for private enterprise, reforms could simultaneously remove regulations on opening and closing a business while permanently closing the agencies that had previously enforced those regulations. This would send a credible signal to that current reforms 
are breaking from the past given that the previous means of enforcing those regulations are no longer available. However, reformers must be cognizant of how ongoing conflict influences perceptions regarding who the true reformers are and the legitimacy of announced reforms. For example, if citizens are not confident that property rights will be protected after conflict ends, removing barriers to business and investment will do little to generate development.

\section{THE KNOWLEDGE TRAP}

Knowledge plays a pivotal role in economic reconstruction efforts. As practitioners are wellaware, understanding the conditions at the 'grass-roots' level is essential for effective implementation of economic reforms. But acquiring, processing, and understanding this informal and indigenous knowledge is quite difficult, if not impossible. In the context of reconstruction, the knowledge trap results from the inability of reconstruction officials to have the information and knowledge necessary to craft context-specific reforms and policies. The assumption that external policy makers do have the requisite knowledge to design and implement first-best economic institutions in order to develop a market economy can be conceptualized as a 'fatal conceit'. Nobel Laureate F.A. Hayek (1988: 27) described the fatal conceit as the presumption that "man is able to shape the world around him according to his wishes." This is precisely the logic underpinning recent reconstruction efforts as illustrated by Stewart (2010), who notes that the plans for reconstruction in Afghanistan tap into "an Enlightenment faith that there is nothing intrinsically intractable about Afghan culture and society and that all men can be perfected (to a Western ideal) through the application of reason and the laws of social science."

To understand the importance of the knowledge trap, consider that a key part of most economic reconstruction efforts is the implementation of a market economy based on a multi- 
pronged plan. With such plans, it is implicitly assumed that (1) the knowledge necessary to effectively design a market economy can be possessed and (2) the consequences (negative or positive) of implementing this multi-pronged plan can be forecasted ex ante. However, attempts to plan and implement markets ignore the complex chain of experiments, choices, errors, and informal institutions which must emerge over time for functioning markets to operate. Robust markets are not planned, but are instead largely the result of emergent norms and institutions which facilitate interaction and exchange. The irony of the fatal conceit is the belief that planners have the sufficient information and knowledge to design and implement markets, which are desirable precisely because they are best able to deal with the fact that knowledge is dispersed and context specific (Hayek 1945).

This is especially important considering that many actors involved in reconstruction lack contextual knowledge that is crucial to accomplishing the desired ends. At the beginning of economic reconstruction efforts in Afghanistan, for instance, "governments, UN agencies, multinational lending institutions, universities, and NGOs were preparing concept papers on how to start reconstructing Afghanistan, but nobody had a clue about the country. None of the agencies had the capacity or the contracts to be able to consult Afghans about their basic needs or development priorities" (Rashid 2009: 171), Along with the classical knowledge pitfalls of economic planning, the lack of historical knowledge, cultural understanding, and general economic reconstruction experience in general significantly hampered efforts to rebuild the economies of Afghanistan and Iraq. ${ }^{\text {iii }}$

\section{The knowledge problem}


The knowledge problem presents a significant hurdle for economic reconstruction efforts that take place during ongoing conflict. In general economic development practices, Pritchett and Woolcock (2004: 197), note that “valuable local 'practices'--idiosyncratic knowledge of variables crucial to the welfare of the poor (e.g. soil conditions, weather patterns, water flows)-get squeezed out, even lost completely, in large centralized development programs." Stephens and Ottaway (2005) provide evidence for this claim in the context of reconstruction efforts in Afghanistan, finding that the roof designs for schools and health clinics were not sufficient to support snowfall during the winter season, resulting in the collapse of many. Such experiences are not unexpected; Pritchett and Woolcock (2004) argue that neglecting local knowledge and engagement can lead to technological mistakes. The difficulties in Afghanistan and Iraq have been further exacerbated by the lack of security, which as discussed above threatens infrastructure projects even where they are successful.

Easterly (2006) argues that development efforts are led by two different groups of individuals: 'planners,' who engage in top-down administration and cannot acquire nor processdispersed and context-specific knowledge, and 'searchers,' who operate at the grass-roots level and utilize such knowledge to engage in effective economic and social development. In the context of economic reconstruction, one could refer to the above failures as an inevitable consequence of planners-led efforts whereas one could look at the successes of Greg Mortenson's construction of schools in Pakistan and Afghanistan, for instance, as a result of effectively utilizing the knowledge, connections, and historical experiences specific to particular villages and tribal elders (Mortenson and Relin 2006).

To illustrate the overemphasis on planning that pervades economic reconstruction efforts, consider again the U.S. military's counterinsurgency and stability operations field manuals, 
which inform military doctrine regarding economic reconstruction and provide a list of overarching institutional and macroeconomic goals. ${ }^{i v}$ When economic reconstruction efforts take place during conflict, military officials are the central players given the need to secure peace. Therefore, it makes sense to consider the knowledge problem in the context of militaryled economic reconstruction.

Among the military's goals and objectives along 'logical lines of operations' for economic development are the (1) mobilization/development of local economic activity (manufacturing, services, agriculture); (2) initiation of contracts with local businesses to stimulate trade; (3) reconstruction of commercial infrastructure (banks, transportation, markets, currency); (4) support of broad-based economic opportunity (micro to macro development); (5) support of a free market economy (5-5). In the counterinsurgency field manual planning schematic, this multi-pronged plan is restoration of the "freedom to conduct lawful commerce" (U.S. Army/Marine Corps, 2007: 5-5). ${ }^{\mathrm{v}}$

While positing strategies and prioritizing goals for economic reconstruction is necessary for developing the 'blueprint' for donor-led planning, the implementation of these plans is entirely different matter. These 'blueprints' for reconstruction and counterinsurgency efforts, while laudable in the abstract, capture the essence of the knowledge trap because they fundamentally assume that planners can design and implement a logical and cohesive plan to rebuild an entire economy. ${ }^{\mathrm{vi}}$

\section{Strategies for avoiding the knowledge trap}

In order to carry out large-scale, top-down, and overarching macroeconomic reforms, exogenous reformers must necessarily abstract from complex context-specific intricacies such as local belief 
systems, context-specific knowledge of time and place, informal institutions, and historical experiences, because there is no feasible approach to accumulating this information in its entirety. Therefore, the only true solution to the knowledge trap is to recognize the binding knowledge constraints on human planning and take these lessons into account when contemplating or formulating future economic reconstruction efforts.

Smaller scale reforms and actions, which make these knowledge constraints less binding (but not completely absent), are more likely to succeed (see Schilderman 2004). Decentralization of economic development efforts is especially important in Afghanistan. As noted by Rashid (2009: 197), “Afghanistan had always had a weak, decentralized state where the ruler governed through consensus over a confederation of tribes and ethnic groups." Administering aid projects through the auspices of the centralized Afghan national government is likely to be ineffective given the historical decentralized nature of Afghanistan's political decision making power (see Isby 2010). The demographics of the country also call for greater dispersion of policy decision making power. Afghanistan's population of roughly 30 million people is largely scattered among 20,000 remote, typically mountainous villages (Stewart, 2010).

There is some evidence that smaller scale movements can be effective. In the case of Iraq, for instance, Berman, Felter and Shapiro (2009) find that the violence-reducing effect of the $\$ 2.9$ billion in American reconstruction funds allocated through the Commander's Emergency Response Program (CERP) was found to be particularly effective after the troop surge. These funds were essentially allocated for small-scale projects and were at the discretion of military commanders. Because the surge led to an operational change in the way troops were deployedfor instance, greater forward operating base deployment and communication with indigenous actors - this led to a greater understanding of communities' needs and therefore a greater 
reduction in violence was seen after the change in tactics. CERP funds have also been administered in Afghanistan. Between fiscal years 2003 and 2009, CERP funds increased from \$40 million to $\$ 683$ million (Isby 2010: 358).

Of course, smaller-scale reforms and actions are less likely to influence the overarching framing of economic reconstruction efforts (Lyons 2009) yet a greater reliance on indigenous action may produce more effective results. Another strategy is to incorporate local citizens into the reconstruction design and process. By allowing those individuals with theknowledge (and incentives) specific to the contextual environment to lead reconstruction efforts, this can bypass the incapacity of planners to implement reforms and may also help to overcome the problems with domestic legitimacy and ownership associated with the credible commitment problem. In many cases, these individuals possess local knowledge of the language, culture, and history of the region and typically are seen as legitimate in the eyes of the citizens in these regions. Further, they understand the channels of logistics and have connections with fellow citizens. This can also mitigate aid 'blowback' where negative and violent unintended consequences may emerge after the initiation of reconstruction reforms.

The U.S. military has recognized the importance of local integration by the launching of Provincial Reconstruction Teams (PRTs) in Afghanistan. Allowing citizens, elders, and local government officials operating at the grass-roots to engage with individuals from NGOs, IGOs, and multinational corporations can lead to increased sharing of knowledge, ideas, beliefs, values, and feasible approaches to economic reconstruction. Yet problems have been noted with the increased employment of PRTs throughout the country. According to Isby (2010: 356), “...in more secure provinces, PRTs are sometimes duplicating Afghan government functions or competing with local officials. In November 2008, President Karzai complained that PRTs were 
creating a "parallel government" to his own in the countryside, and other Afghans perceived that many of the resources devoted to some PRTs were absorbed by multiple layers of contractors and sub-contractors, foreign and Afghan, so that little actually reached the grassroots."

In Afghanistan, a World Bank-led national development plan called the National Solidarity Program has proved highly successful (Rashid 2009: 184). The program allowed for committees in communities across the country to assess development priorities and were then allocated small grants (around \$30-60 thousand) for the implementation of development projects. As Rashid (2009: 185) illustrates, NGOs involved with the program “...helped villagers with the decision making process and in building projects such as digging wells and reservoirs and building bridges and schools." This decentralized approach to economic development is likely to be more successful given that it taps into the local knowledge of around 20,000 Community Development Councils (Zoellick 2008). As described by Miliband (2010), “[The village councils] have not just designed but implemented almost 40,000 development projects, and are now forming, from the bottom up, district councils." In addition to ameliorating the knowledge trap, this also aids in securing areas of the country because local citizens and political authorities have the incentive to maintain order and resist insurgents.

\section{THE POLITICAL ECONOMY TRAP}

In conflict-stricken societies, economic reconstruction is one part of the broader strategy to eventually end conflict. However, economic reconstruction does not take place in isolation as eeconomic and political reconstruction efforts are inextricably linked. For instance, if political institutions are characterized by corruption and unchecked power, this will stifle economic activity because property rights may be insufficiently protected or the regulatory hurdles 
(including bribes) to exchange, investment, and innovation may be too significant for local citizens or firms to overcome. Conversely, success (or failure) in different economic sectors may generate different political impulses by local citizens (e.g. support for less or more free trade, levels of redistribution, etc.). The implementation of economic reforms within the context of political agreements is especially difficult (Del Castillo 2001). The political economy trap refers to the idealized view of politics and democracy which pervades reconstruction efforts. This view assumes that political and economic goals are compatible and neglects the tradeoff between democratic and economic outcomes. Further, this view overemphasizes the benefits of democratic political systems while understating the potential costs of such systems on economic reconstruction efforts.

\section{The tradeoff between democracy and economic goals}

The political economy trap can adversely affect economic reconstruction in several key ways. First, the idealized view of democracy overlooks the fact that unchecked democracy can produce a variety of negative outcomes. While reformers typically develop a comprehensive list of targets and goals to attain related to the establishment of democratic political systems in conflicttorn countries (e.g. the holding of elections), implementation must be carefully performed. For instance, Flores and Nooruddin (2009: 5) find that "countries that undergo extensive democratization in the immediate postconflict period recover more slowly than countries that do not." This may be because "typically early elections in a highly polarized society empower elites, senior military leaders, and organized criminal elements" (U.S. Department of the Army, 2008: 1-18). This highlights how important the proper consolidation of democracy and institutions is for effective economic reconstruction, especially where conflict is still ongoing. 
Absent effective constraints, democracy can produce illiberal outcomes-political, economic, and legal - that can do significant harm to efforts to foster economic reconstruction. When analyzing donor-led reconstruction goals in Afghanistan, Montgomery (2004: 36) illustrates some of the democracy-economic tradeoffs as such:

(1) the rule of law can degenerate into the rule of lawyers--litigious, costly, and dilatory; (2) economic efficiency can turn into profligacy--piratical and predatory; (3) free speech can reward superficiality and extremism; (4) the demand for unfulfilled rights can invite invidious reverse discrimination; (5) checked-andbalanced governmental institutions can yield policy stasis.

The above five factors shed light on the need to establish effective constraints to ensure that reconstruction efforts result in stable political and economic orders. Yet creating these checks and balances is by no means a simple task, and social scientists and practitioners typically lack the knowledge of how to design effective comprehensive constitutional rules that will stick over the long run. This is because formal institutions, such as constitutions, must be grounded in informal customs and belief systems, which are largely beyond the reach of policy (North 2005; Boettke, Coyne and Leeson 2008). Where there is a disconnect between existing informal institutions and desired formal institutions, the latter will not be viewed as legitimate by citizens further contributing to the credible commitment trap discussed earlier.

Second, the idealized view of democracy often leads outsiders to overlook the tensions that may exist between the dual goals of establishing democratic political institutions and constructing the foundations of a market economy. These tensions may preclude the emergence of large-scale and first-best reforms; for instance, the privatization of state-owned enterprises or the removal of all tariffs and non-tariff barriers to trade may not occur because powerful interests drive policy efforts in the other direction. Allowing for self-determination through democracy can lead to demands by citizens that run counter to the free market economic plans often 
envisioned by reformers. When this happens, it presents a conundrum because implementing reconstruction plans requires either preventing democratic participation or ignoring the results.

For instance, when the highest ranking Shi'a Muslim scholar in Iraq, Grand Ayatollah alSistani, issued a fatwa calling for general elections in June 2003, this led the CPA to ultimately abandon plans to appoint a body to construct a national constitution (Wong 2004). This had real effects on economic outcomes since the CPA was unable to have oversight over the writing of a constitution that could have provided a foundation for a permanent government, which would have led to stability and the encouragement of economic activity, which was viewed as a central aspect of the counter-insurgency strategy.

Third, the overly optimistic view of democracy can lead to a neglect of the status quo. This happens because in assuming the ideal reformers often lose focus of the realities of the situation they face. Buchanan (1975) emphasizes that all reforms must start from the 'here and now' by recognizing the status quo and the associated constraints. The status quo refers to the array of existing formal and informal institutions, economic and political actors, and other particularities of post-conflict settings. Focus on the ideal, and the resulting failure to appreciate the status quo, has contributed to the failure of various reconstruction efforts. One well-known example can be found in Iraq where, instead of rebuilding governmental institutions from scratch, the CPA implemented a process of de-Ba'athification through the existing government apparatus. The intent of this policy was to minimize disruptions to the government's provision of services following the 2003, U.S.-led invasion. Yet as Allawi (2007: 161-2) explains, this proved problematic as the CPA did not have enough competent staff to operate the government. Hence, the lack of appreciation for the status quo-i.e. the recognition and understanding of pre- 
invasion governance structures and the associated binding constraints-has contributed to significant hurdles for economic reconstruction efforts in Iraq.

The status quo in both Afghanistan and Iraq also involved ongoing conflict, corruption, and power vacuums, which has made attempts to achieve both political and economic reconstruction that much more difficult. As in the case of the credible commitment problem, violent insurgencies in these countries have created uncertainty regarding the final distribution of political power. This political complexity has contributed to uncertainty regarding the dynamics of economic institutions and modes of coordination. Local citizens may be less likely to coalesce around economic reforms and reconstruction projects if their political demands lead them to join the ongoing insurgencies.

\section{Strategies for avoiding the political economy trap}

Those tasked with carrying out reconstruction efforts must be cognizant of the tradeoff between democratic goals and economic outcomes. The focus must be shifted away from the idealized view of democracy and towards finding ways to implement effective constraints on political decision makers to ensure that economic reconstruction efforts are not in conflict with political behaviors. However, given the uncertainty due to ongoing conflict, this can be difficult to accomplish. Recognizing, understanding, and appreciating the status quo and the associated constraints in post-conflict regions will provide a sounder foundation from which to implement policies.

Given the democracy-economy tradeoff, one possible strategy for overcoming the political economy trap is to prioritize political reconstruction over economic reconstruction or vice versa. For instance, del Castillo (2008: 41) argues that "should a conflict arise between 
peace (political) and development (economic) objectives, the first one should be paramount at all times. Because peace is a precondition for sustainable development, all actors should recognize and accept that political priorities will often constrain economic policymaking." According to General James Conway, Commandant of the Marine Corps, in fielding a question regarding the conditions that would be suitable for a significant troop withdrawal:

...a military force shapes the environment. We can't fix the economy, we can't fix the government. What we can do is affect the security. Now we can aid in these other things, but, for all intents and purposes, we shape the environment that allows these other lines of operations...to take place. Initially, in both Iraq now and in Afghanistan, we've had to do that at the start by ourselves. But increasingly, our doctrine calls for turning that over to host nation security forces...that's why we are partnering right now almost on every patrol with the Afghan security forces...that's why we want to posture the police so they can be successful...transitioning host nation forces to the point that they can do those things...when we think that we have sufficiently beaten down the insurgency in the area, we have sufficiently built up the Afghan capability to deal with what's there...then I think we have done the essence of what we were sent there to do (CSPAN 2010).

In some sense, the cessation of conflict and the promotion of security of person and property may very well be necessary and sufficient conditions to allow for economic growth and development. It should be realized that this approach places limits on the scale and scope of economic reconstruction efforts and implies that large-scale, first-best economic reforms are unlikely to be effective since they are more likely to conflict with political and security objectives. This can be problematic considering the historical and contemporary influences of conflict on human and social capital. This tension between political and economic goals is likely to be even greater in instances of ongoing conflict as efforts are focused on ending violence and securing peace given the uncertainty of the distribution of political power and nature and stability of political institutions. 


\section{THE BUREAUCRACY TRAP}

There are appreciable limits to implementing economic reconstruction goals through bureaucratic channels. There have been scathing critiques of reconstruction efforts in Afghanistan and Iraq due to the lack of effective planning and cross-coordination among different agencies and reconstruction officials. There have also been numerous reports of corruption, waste, nepotism, and inefficiency, both on the part of the Afghan and Iraqi national governments but also by foreign reconstruction officials. For example, Stephens and Ottaway (2005) have documented the progress of a program to construct Afghan schools and health clinics, finding that the program suffered from a lack of coordination and poor planning due in part to the desire to have something completed before the 2004 Afghan presidential elections.

These inherent inefficiencies have led to continued calls for "improved coordination" and "better planning" on the part of bureaus. For instance, the U.S. Army's stability operations field manual (2008: 1-3) calls for 'unity of effort' among the array of actors involved in a stability operation, including the "synchronization, coordination, and/or integration of the activities of governmental and nongovernmental entities with military operations to achieve unity of effort." However, this focus on 'streamlining' bureaucracies places disproportionate emphasis on the role of bureaucracy in reconstruction efforts while neglecting the key role played by ordinary citizens acting in an entrepreneurial manner to solve the problems facing post-conflict societies. The bureaucracy trap emerges when there is an overreliance on bureaucracies in economic reconstruction efforts. Avoiding this trap therefore involves an understanding of the industrial organization of bureaucracies, including the incentives and constraints faced by bureaucrats, as well as an appreciation for the capacity for 'searchers' to coordinate scarce resources and find solutions to problems. ${ }^{\mathrm{vii}}$ 


\section{Bureaucracy and economic reconstruction}

Agencies engaged in economic reconstruction efforts receive their budgets from an array of government actors. Budgets are allocated based on relationships with these actors, as well as on the logistical and compensatory needs of each bureau. Yet financial resources are scarce and each bureau is therefore competing with other agencies over a limited budget. The incentives created by this process result in predictable behaviors among those working in these bureaucracies and these behaviors influence the process of economic reconstruction in a number of ways.

First, bureaus involved in economic reconstruction efforts will attempt to receive the largest possible share of financial resources and the associated influence over reconstruction efforts. This typically involves investing resources in signaling the relative importance of one bureau over others. Second, this intrinsically creates an important tension in reconstruction efforts: agencies should be united in the common goals of reconstruction (e.g. security, amelioration of poverty, infrastructural development, etc.) yet they are instead competing with one another for funds and influence. This often leads to efforts to develop a specialization that differentiates one agency from the others in order to receive a larger part of the fixed budget. Each bureau has its own agenda, which may clash with the agendas of other agencies as well as with the overarching goal of successful economic reconstruction. Third, bureaus will tend to exhaust their entire budgets while continually seeking financial appropriations in order to increase the size and scope of the agency. The failure of a bureau to spend its allocated budget typically leads to budget reductions in subsequent years. This creates the incentive to ensure that budgets are exhausted even if wasteful expenditures are necessary to achieve this outcome. This 
inherently runs counter to ensuring that reconstruction costs are minimized while the benefits to the citizens are maximized. This waste is magnified by the lack of adequate feedback mechanisms in bureaucratic settings making it difficult for bureaucrats to accurately gauge the effective allocation, and reallocation, of resources to high-return uses (Mises 1983). Lastly, bureaucracies are typically judged on the basis of readily observable outputs which do not necessarily coincide with the goals of long-run economic reconstruction and development (see Easterly 2003). ${ }^{\text {viii }}$

These four factors have had substantial impacts on reconstruction efforts in Iraq and Afghanistan. For instance, infighting for control over Iraq reconstruction policy between the U.S. Department of Defense and the U.S. State Department became highly acrimonious (Phillips 2005: 7). Diamond (2005: 28-9) claims that "a number of U.S. government agencies had a variety of visions of how political authority would be reestablished in Iraq. In the bitter, relentless infighting among U.S. government agencies in advance of the war, none of these preferences clearly prevailed."

Yet another factor affecting the capacity for bureaucracies to effectively engage in economic reconstruction is decision making and the flow of information within these organizational structures. Bureaucratic rules tend to be rigid in nature which often prevents flexibility to rapidly changing conditions. This poses a problem for economic reconstruction efforts which typically take place in the context of uncertainty and constant change-especially in the cases of Afghanistan and Iraq, where violent insurgencies are still ongoing. As Rondinelli (2004: 12) explains, "Many of the decisions about how to promote the development of Afghanistan are likely to be made rapidly, reactively, and in response to uncertain and ever- 
changing political forces. Careful deliberation is likely to be in short supply in the face of rapidly changing political trends and complex social and cultural conditions in Afghanistan.”

To provide a concrete example of this logic, consider the economic reconstruction of Iraq, where bureaucratic waste and inefficiency have been magnified as a result of the absence of effective feedback and accountability mechanisms (Glanz 2006). Specifically, consider the $\$ 644$ million "Community Stabilization Program" (CSP) in Iraq, which was suspended due to significant fraud and waste. An audit by the USAID's Inspector General found that some of the funds allocated specifically for weakening the insurgency actually went to insurgents, as well as to corrupt community leaders and CSP representatives (USAID Office of the Inspector General, 2008: 8). As another example, consider that a more recent audit published in July 2010 found that that U.S. Department of Defense was unable to property account for $96 \%$ of the $\$ 9.1$ billion funds it has received since 2004 through the Development Fund for Iraq for reconstruction activities (Special Inspector General for Iraq Reconstruction 2010).

In Afghanistan, the story has not been much different. The United States spent around \$860 million on police training, with Rashid (2009: 205) concluding that the "results were almost totally useless." This is because "DynCorp [a State Department contractor] was training the police to fight an insurgency rather than win hearts and minds in their localities." The actions of the local police thereafter were observed to be as "rapacious" as they were before (Rashid 2009: 205). According to the former finance minister of Afghanistan, Ashraf Ghani, "International technical assistance is considered to be largely wasted...hundreds of millions of dollars have gone into technical assistance only to increase corruption and misgovernance" (Isby 2010: 334). 


\section{Strategies for avoiding the bureaucracy trap}

The overemphasis on improving coordination and planning within and between bureaus ignores the constraints on what bureaucracies can actually achieve in economic reconstruction during conflict. Coordination is a necessary but insufficient condition for successful economic reconstruction because real constraints exist on bureaucratic activity no matter what the level of coordination. Perhaps more importantly, this focus puts unrealistic faith in increased bureaucratic central planning, which is the very antithesis of the free markets that reconstruction authorities seek to engender through economic reconstruction.

The bureaucracy trap illustrates that overreliance on bureaus to coordinate reconstruction efforts can hamper economic growth and development. The main concern is that the central planning associated with bureaucracy results in the systematic disregard for the capacity of ordinary citizens and 'searchers' to act entrepreneurially to find solutions for the problems of economic reconstruction. One example of the power of private initiative is the mobile phone industry in Iraq (The Economist, 2009). With 20 million subscribers in a county of 27 million citizens, mobile phones have become a tool of commerce and have allowed for greater interpersonal communication. According to Isby (2010: 343), in Afghanistan "communications and the spread of cell phones have proven a great success, funded almost exclusively by the private sector, and has managed to avoid corruption. This was largely carried out by Afghans working in the private sector, borrowing money and acquiring technology from outside as required, rather than relying on donor nations." While many reconstruction activities must inherently be dealt with through bureaucratic channels, it is critical to realize the limits of bureaucratic activity and the importance of private initiative and decentralization for sustainable economic recovery. 


\section{CONCLUSION}

The overarching implication of our analysis is that there are significant constraints on what economic reconstruction can accomplish. These constraints are even more significant in cases of ongoing conflict and insurgency since this context contributes to additional tensions between political and military actors, as well as citizens. Reconstruction amidst violence places the military at the core of the reconstruction effort and leads to a tension in various goals and strategies which often leads to outcomes which run counter to the goals of economic reconstruction. Moreover, the involvement of the military in economic reconstruction stretches military personnel beyond their comparative advantage — the use of force — and asks them to act on knowledge and information which they cannot possibly possess.

The economic reconstruction traps put forth in this paper indicate that the first-best, and often the second- and third-best policies, will not be realistic given the incentives, constraints, and knowledge limitations inherent to economic reconstruction efforts. This implication may be apparent, but as the many examples discussed in this paper indicate, actual efforts to engage in economic reconstruction amidst conflict tend to neglect these traps and the resulting constraints. The failure to appreciate the traps of economic reconstruction sheds light on many of the failures in Afghanistan and Iraq to date and provide insight into what should be avoided in future efforts in similar settings.

Finally, we must point out that another possibility not captured in our analysis is that the failure of economic reconstruction may not be due specifically to the traps discussed above, but rather because of inappropriate or irrelevant strategies and policies underpinning the initial occupation and reconstruction. Our analysis indicates that even under a first-best scenario, 
where the initial occupation and reconstruction is legitimate and based on sound strategies and policies, the desired end of economic reconstruction may not be achieved due to some combination of the four reconstruction traps. If we ease this assumption and recognize that inappropriate policies and strategies may underpin the initial occupation and reconstruction, this provides even more reason to be skeptical that economic reconstruction officials will be successful in achieving their goals during protracted insurgencies. 

* Corresponding author: Christopher J. Coyne (ccoyne3@gmu.edu), Department of Economics, George Mason University, MSN3G4, Fairfax, VA 22030; Adam Pellillo (adam.pellillo@mail.wvu.edu), West Virginia University, Department of Economics, PO Box 6025, Morgantown, WV 26506-6025.

${ }^{\mathrm{i}}$ As Acemoglu and Robinson (2006: 193) explain, credibility becomes an issue when there is a disjoint between those holding power and the beneficiaries of announced reforms because those holding power may renege on their vocalized intent in later periods and beneficiaries have limited recourse when they do so.

${ }^{i i}$ As described by Stewart (2010), "Frustrated by a lack of progress, the U.S. and its allies have oscillated giddily between contradictory policies [in Afghanistan]. The British government that once championed more generous budgetary support for the Kabul government now portrays it as corrupt, semi-criminal, ineffective, and illegitimate."

iii According to Isby (2010: 349), "the donors—international, governments, and NGOs—have demonstrated too often a willingness to embrace quick-fix solutions and imported templates, with the context and true nature of Afghan society largely ignored."

iv While the US Army/Marine Corps Counterinsurgency Field Manual and the Stability Operations Field Manual illustrate the U.S. military's overarching macroeconomic goals in economic reconstruction efforts, the manuals are first and foremost geared towards counterinsurgency operations.

${ }^{v}$ Among the U.S. military's short-term goals for post-conflict recovery include the "(1) Security [of citizens] from insurgent intimidation and coercion, as well as from nonpolitical violence and crime; (2) Provision for basic economic needs; (3) Provision of essential services, such as water, electricity, sanitation, and medical care; (4) Sustainment of key social and cultural institutions; and (5) Other aspects that contribute to a society's basic quality of life" (U.S. Army/Marine Corps, 2007: 2-2). The military also seeks to engage in economic and infrastructure development (U.S. Army/Marine Corps, 2007: 1-19). These goals are relatively more tractable vis-à-vis the set of goals listed for overarching economic development. This is because (1) the knowledge required for such endeavors is not as context-specific, (2) they are immediate in time frame and are more readily implementable through standard military chains of logistics, and (3) do not involve the level of knowledge or logistics complexity required for overarching economic transformation.

${ }^{\text {vi }}$ U.S. military planners are evidently self-aware of the shortcomings of this strategy. Indeed, in the counterinsurgency field manual, it is claimed that "many commanders are unfamiliar with the tools and resources 
required for promoting economic pluralism" (8-16). What is overlooked is whether military commanders and exogenous policymakers can ever possess the relevant knowledge to achieve the goals dictated by the counterinsurgency and stability operations field manuals. The knowledge problem-which emphasizes the importance of context-specific knowledge of time and place—suggests they cannot.

vii There is an array of bureaucracies involved in post-conflict economic reconstruction including government agencies, IGOs and NGOs. Although our analysis could be applied to any of these organizations, we limit our focus to government agencies since they are typically the largest bureaucracies involved in economic reconstruction and usually play the largest role in terms of planning, implementation and oversight of reconstruction plans.

viii According to Rashid (2009: 177), at the beginning of economic reconstruction efforts in Afghanistan, "Quickimpact projects became a Washington favorite. These were swift and cheap, such as digging a well, rebuilding a small bridge, or repairing a broken-down school building, and were supposed to convince the population that reconstruction was moving ahead. Instead, such projects invariably helped only the local warlord or commander the CIA was supporting.” 


\section{REFERENCES}

Acemoglu, D. and Robinson, J. (2006) Economic Origins of Dictatorship and Democracy. Cambridge, UK: Cambridge University Press.

Adam, C., Collier, P. and Davies, V. (2008) Post-conflict monetary reconstruction. World Bank Economic Review 22(1), 87-112.

Addison, T. and Bruck, T. (eds.) (2009) Making Peace Work: The Challenges of Social and Economic Reconstruction. New York, NY: Palgrave-Macmillian.

Allawi, A.A. (2007) The Occupation of Iraq: Winning the War, Losing the Peace. New Haven: Yale University Press.

Bastian, S., and Luckham, R. (eds.) (2003) Can Democracy Be Designed? The Politics of Institutional Choice in Conflict-Torn Societies. New York: Zed Books.

Berman, E., Felter, J. and Shapiro, J. (2009) Can hearts and minds be bought? The economics of counterinsurgency in Iraq. NBER Working Paper, 14606.

Boettke, P.J., Coyne, C.J. and Leeson, P.T. (2008) Institutional stickiness and the new development economics. American Journal of Economics and Sociology, 67(2), 331-358.

Boyce, J.K. (ed.). (1996) Economic Policy for Building Peace: The Lessons of El Salvador. Boulder, CO: Lynne Reinner.

Boyce, J.K. (2002) Investing in Peace: Aid and Conditionality after Civil Wars. Oxford: Oxford University Press.

Buchanan, J. (1975) The Limits of Liberty. Chicago: Chicago University Press.

Chimni, B.S. (2003) Post-conflict peace-building and the return of refugees: concepts, practices, and institutions," In, Refugees and Forced Displacement: International Security, Human Vulnerability, and the State, Edward Newman and Joanne van Selm (eds.), New York: United Nations University Press.

Coalition Provisional Authority (CPA) (2003) CPA official website: http://www.cpairaq.org/regulations/. Last Accessed December 19, 2009.

Collier, P. (1994) Demobilization and insecurity: A study in the economics of the transition from war to peace. Journal of International Development, 6(3), 343-351.

Collier, P. and Hoeffler, A. (2000) Aid, policy, and growth in post-conflict societies. European Economic Review, 48(4): 1125-1145. 
Collier, P. (2009) "Post-conflict recovery: how should policies be distinctive?" Journal of African Economics, 18(suppl 1): i99-i131.

Council on Foreign Relations (2005) In the wake of war: improving US post-conflict capabilities. Available at http://www.cfr.org

Coyne, C.J. (2008) After War: The Political Economy of Exporting Democracy. Stanford: Stanford University Press.

Coyne, C.J. and Boettke, P.J. (2009) The problem of credible commitment in reconstruction. Journal of Institutional Economics, 5(1), 1-23.

CSPAN. 2010. War in Afghanistan and Marine Corps policies. Transcript and video available at http://www.c-spanvideo.org/program/295155-1

Del Castillo, G. (2001) Post-conflict reconstruction and the challenge to international organizations: the case of El Salvador." World Development, 29(12), 1967-1985.

Del Castillo, G. (2008) Rebuilding War-Torn States: The Challenges of Post-Conflict Economic Reconstruction. New York: Oxford University Press.

Demekas, D.G., McHugh, J., and Kosma, T. (2002) The economics of post conflict aid. IMF Working Paper WP/02/198. Washington: International Monetary Fund.

Diamond, L. (2005) Squandered Victory: The American Occupation and the Bungled Effort to Bring Democracy to Iraq. New York: Henry Holt.

Dobbins, J., McGinn, J.G., Crane, K., Jones, S.G., Lal, R., Rathmell, A., Swanger, R.M., Timilsina, A.R. (2003) America's Role in Nation-Building. Santa Monica, CA: RAND Corporation.

Dobbins, J., Jones, S.G., Crane, K., Rathmell, A., Steele, B., Teltschik, R., Timilsina, A.R. (2005) The UN's Role in Nation-Building. Santa Monica, CA: RAND Corporation.

Easterly, W. (2003) The cartel of good intentions: the problem of bureaucracy in foreign aid. Journal of Policy Reform, 5(4), 223-250.

Easterly, W. (2006) The White Man's Burden. New York: The Penguin Press.

Fearon, J.D. (2007) Iraq's civil war. Foreign Affairs, 86(2), 2-15.

Filkins, D. (2009) Stanley McChrystal's long war. The New York Times, October 14.

Flores, T.E. and Nooruddin, I. (2009) Democracy under the gun: understanding postconflict recovery. Journal of Conflict Resolution, 53(1), 3-29. 
Glanz, J. (2006) Audit describes misuse of funds in Iraq projects. The New York Times, January 25.

Gunter, F.R. (2009) Liberate Iraq's economy. The New York Times, November 15.

Hayek, F.A. (1945) The use of knowledge in society. American Economic Review, 35(4), 519-530.

Hayek, F.A. (1988) The Fatal Conceit: The Errors of Socialism. Chicago: Chicago University Press.

Ikenberry, G.J. (2001) After Victory: Institutions, Strategic Restraint, and the Rebuilding of Order after Major Wars. Princeton: Princeton University Press.

Isby, D. (2010) Afghanistan: Graveyard of Empires - A New History of the Borderland. New York: Pegasus Books.

Kumar, K. (ed.) (1998) Postconflict Elections, Democratization, and International Assistance. Boulder: Rienner.

Lyons, M. (2009) Building back better: the large-Scale impact of small-scale approaches to reconstruction. World Development, 37(2), 385-398.

McChrystal, Stanley. (2009) COMISAF Initial Assessment. Available at http://www.washingtonpost.com/wpdyn/content/article/2009/09/21/AR2009092100110.html

Miliband, D. (2010) How to end the war in Afghanistan. New York Review of Books, April 29, 2010.

Montgomery, J.D. and Rondinelli, D.A. (eds.) (2004) Beyond Reconstruction in Afghanistan: Lessons from Development Experience. New York: Palgrave MacMillan.

Montgomery, J.D. (2004) Supporting postwar aspirations in Islamic societies. In Montgomery, J.D. and Rondinelli, D.A. (eds.). Beyond Reconstruction in Afghanistan: Lessons from Development Experience. New York: Palgrave MacMillan.

Mises, L. (1983) Bureaucracy. Grove City, PA: Libertarian Press, Inc.

Mohammed, R. and Leland, J. (2009) In heart of Iraq, a plan to revive the pulse of a central artery. The New York Times, December 29.

Mortenson, G. and Relin, D.O. (2006) Three Cups of Tea: One Man's Mission to Promote Peace... One School at a Time. New York: Penguin Books. 
Norland, R. (2010) Poison gas used on girls' schools, Afghan officials say. New York Times, August 31.

North, D. (2005) Understanding the Process of Economic Change. New Jersey: Princeton University Press.

Phillips, D.L. (2005) Losing Iraq: Inside the Postwar Reconstruction Fiasco. New York: Basic Books.

Pritchett, L. and Woolcock, M.. 2004. Solutions when the solution is the problem: arraying the disarray in development. World Development, 32(2), 191-212.

Rashid, A. (2009) Descent into Chaos: The United States and the Failure of Nation Building in Pakistan, Afghanistan, and Central Asia. New York: Penguin Books.

Rathmell, A. (2005) Planning post-conflict reconstruction in Iraq: what can we learn? International Affairs 81(5): 1013-1038.

Rodrik, D. (1989) Promises, promises: credible policy reform via signaling. The Economic Journal 99(397), 756-772.

Rondinelli, D.A. (2004) International goals and strategies for Afghanistan's development: reconstruction and beyond. In Montgomery, J.D. and Rondinelli, D.A. (eds.) Beyond Reconstruction in Afghanistan: Lessons from Development Experience. New York: Palgrave Macmillan.

Schilderman, T. (2004) Adapting traditional shelters for disaster mitigation and reconstruction: experiences with community-based approaches. Building Research and Information, 32(5), 414-426.

Sobhan, R. (2002) Aid effectiveness and policy ownership. Development and Change 33(3), 539-548.

Special Inspector General for Iraq Reconstruction (2010) Development fund for Iraq: Department of Defense needs to improve financial and management controls. July 27, SIGIR 10-020.

Stephens, J. and Ottaway, D.B. (2005) A rebuilding plan full of cracks. The Washington Post November 20.

Stewart, R. (2010) Afghanistan: what could work. The New York Review of Books, 57(1), January 14, 2010 Issue.

The Economist. 2009. Iraq's mobile-phone revolution: better than freedom? November 14. 
Transparency International. (2009) Corruption perceptions index 2009. Accessed online at http://www.transparency.org/policy_research/surveys_indices/cpi/2009/cpi_2009_ta ble on January 10, 2010.

Trofimov, Y. (2010) U.S. rebuilds power plant, Taliban reap a windfall. Wall Street Journal, July 13.

USAID Office of the Inspector General (2008) Audit of USAID/Iraq's community stabilization program." Audit Report No. E-267-08-001-P. Available online: http://pdf.usaid.gov/pdf_docs/PDACN242.pdf.

U.S. Army/Marine Corps (2007) Counterinsurgency Field Manual (U.S. Army Field Manual No. 3-24/Marine Corps Warfighting Publication No. 3-33.5 Chicago: University of Chicago Press.

U.S. Department of the Army (2008) Stability Operations Field Manual (U.S. Army Field Manual No. 3-07), University of Michigan Press.

Williams, G.H. (2003) Post Conflict Reconstruction: On the Critical Path to Long-Term Peace. U.S. Army War College Senior Service College Fellowship Program Strategy Research Project. Carlisle Barracks: U.S. Army War College.

Wong, E. (2004) Direct election of Iraq assembly pushed by cleric. The New York Times, January 12 .

Zoellick, R. (2010) The key to rebuilding Afghanistan. Washington Post, August 22. 